\title{
Effects of supplementing water spinach (Ipomoea aquatica) to basal diet on growth performance and nutrients digestibility of broiler chickens
}

\author{
A.T. Maung* ${ }^{1}$, K.H. Swe ${ }^{1}$, A.A. Maw ${ }^{2}$, Y.L. Aung ${ }^{1}$ \\ ${ }^{1}$ Department of Animal Science, ${ }^{2}$ Department of Genetics and Animal Breeding, \\ University of Veterinary Science, Yezin, Nay Pyi Taw, Myanmar \\ *Corresponding author: Email: dr.ayethidamaung@gmail.com
}

Journal of Livestock Science (ISSN online 2277-6214) 11: 77-84

Received on 23/1/20; Accepted on 25/3/2020

doi. 10.33259/JLivestSci.2020.77-84

\begin{abstract}
This experiment was conducted to study the effects of supplementing green feed- water spinach (Ipomoea aquatica) to basal diet on growth performance and nutrient digestibility of broiler chickens. A total of 120 male Cobb 500 broiler chickens aged 21 days were randomly allocated to three dietary treatments by using a randomized complete block design (RCBD). Each treatment consisted of five replicates and eight birds per replicate. From 22-49 days, the grower chickens were exposed to the three different experimental diets: diet 1 - basal diet containing $0.4 \%$ vitamin-mineral premix (control), diet 2basal diet containing $0.2 \%$ vitamin-mineral premix $+34.5 \mathrm{~g}$ fresh water spinach (Ipomoea aquatica), and diet 3- basal diet without vitamin-mineral premix $+69 \mathrm{~g}$ fresh water spinach. Growth performances were measured and calculated on weekly basis. On day 49, three birds of each treatment group with almost similar body weight were selected and placed in individual cages. Feed intake was recorded for each bird every day and total faeces were collected on three consecutive days. In order to calculate the digestibility value of experimental diets, the dry matter (DM) and crude protein $(\mathrm{CP})$ content of feed and faeces were determined. There were no significant effects on growth performances through feed consumption, body weight, weight gain and feed conversion ratio (FCR) of broiler chickens. The digestibility of feed DM and feed $\mathrm{CP}$ was not significantly different $(\mathrm{P}>0.05)$ among the treatments. Further, diets supplemented with water spinach had no adverse effect on growth performance and nutrients digestibility of broiler chickens. It can be concluded that the more expensive vitamin-mineral component of the ration can be replaced by the lower cost and widely available water spinach.
\end{abstract}

Keywords: broilers; digestibility; performance; premix; water spinach 


\section{Introduction}

Poultry production is facing high feed cost of $70-75 \%$ of total cost of production. The profit of poultry farming mainly depends on economic feeding of balanced, cheap and quality diets. It is important to pay attention to the formulation of poultry diet using local feed ingredients supplemented with cheaper but quality nutritional supplements (Teguia and Beynen, 2005). Green leafy vegetables are a rich source of nutrients including vitamins and minerals, locally valuable and have low cost for farmers to use as animal feed (Saroeun, 2010).

The plant Ipomoea aquatica belonging to the family Convolvulaceae is a semi-aquatic tropical plant grown as a leafy vegetable. Ipomoea aquatica is commonly called water spinach or morning glory and is highly invasive in several parts of the world, forming dense mats over the surface of water bodies such as lakes, ponds, canals and ditches (Igwenyi et al., 2011). Water spinach is found growing wildly in tropical and subtropical countries, and is cultivated widely in China, Indonesia, Thailand, Vietnam, Myanmar, Philippines, Bangladesh, and in India (Odulate et al., 2014). It is a good source of protein on dry matter basis (Men et al. 2000), and also rich in minerals and vitamins, especially vitamins A (carotene), B1, B2, C and iron (Oomen and Grubben 1978; Naren Toung et al., 1994). This plant also possesses antioxidant activity and moderate anticancer activity. Moreover, it has a medicinal effect on liver diseases, eye diseases and constipation (Prasad et al., 2008).

Water spinach is commonly used by smallholders to feed their scavenging poultry as a supplement mixed with rice bran in rural regions of Cambodia. Using water spinach for local chickens indicates that it is also preferred foliage to provide protein and vitamins for growing chickens (Saroeun, 2010). Nguyen Thi Thuy and Ogle (2005) reported that when layer chickens had access to green feed such as water spinach, the colour of their skin and the egg yolk were improved which makes the products more attractive to the customers. Naren Toung et al. (1994) also indicated that vitamin-mineral premix did not need to be included in diets containing water spinach as no deficiency symptoms of ducks were observed on this diet. The ability of water spinach to supply vitamins and minerals is an important advantage in the rural areas where premixes are not usually available or are expensive.

It is believed that the use of such locally abundant green leaves as feed supplements without doubt can improve the performance of poultry birds through enhanced growth (Offor and Wariboko, 2013). In Myanmar, water spinach is very cheap and widely available plant. However, the supplementation with green feed (water spinach) to the basal diet of broiler chickens as an alternative to vitamin premix has not been investigated yet. Therefore, the present study was to investigate the effect of water spinach (Ipomoea aquatica) supplementation on growth performance and nutrients digestibility of broiler chickens.

\section{Materials and methods}

\section{Experimental site, design, animals and management}

The experiment was conducted at the University of Veterinary Science, Yezin, Nay Pyi Taw, Myanmar. A randomized complete block design (RCBD) was used in this experiment. A total of 120 male Cobb 500 broiler chickens aged 21 days were individually weighed and randomly allocated to three experimental treatments. Each treatment consisted of 5 replicates and 8 birds per replicate. Chickens in all treatments were kept under the similar management condition. Feed and drinking water were supplied ad libitum throughout the experimental period.

Experimental diets and preparation of water spinach

From days 22 to 49, chickens were provided three experimental diets: diet 1- basal diet containing 0.4 $\%$ vitamin-mineral premix (control), diet 2 - basal diet containing $0.2 \%$ vitamin-mineral premix $+34.5 \mathrm{~g}$ fresh water spinach, and diet 3 - basal diet without vitamin-mineral premix $+69 \mathrm{~g}$ fresh water spinach. The diets were formulated to maintain a constant ratio of energy and protein to meet requirements of broiler chickens (NRC 1994). The composition and calculated nutrient contents of grower ration are shown in Table 1.

Fresh water spinach was purchased locally, then thoroughly washed, chopped into $1.5 \mathrm{~cm}$ size, weighed and given directly to the chickens (Figure 1). Water spinach fed to broiler chickens was calculated on an equal amount of vitamin A concentration as compared to the vitamin-mineral premix. The vitamin A and other nutrient components of water spinach are shown in Table 2. The cost differences among dietary treatments by using premix and water spinach in the study are shown in Tables 3 and 4.

\section{Data collection}

Daily feed consumption was noted and body weight of each bird was recorded at the end of each week and repeated weekly up till the last day of the experiment. The average feed consumption, weight gain and feed conversion ratio were calculated on a weekly basis. After the age of 49 days, a digestibility trial was carried out to determine the nutrient utilisation of broiler chickens by total collection method. Three birds of each treatment group with almost similar body 
Table 1- Composition and calculated nutrient contents of grower ration for broilers (22 to 49 days age)

\begin{tabular}{|l|l|l|l|}
\hline Ingredients & Diet 1 (\%) & Diet 2 (\%) & Diet 3 (\%) \\
\hline Maize & 60 & 60 & 60 \\
\hline Broken rice & 7 & 7 & 7 \\
\hline Rice bran & 4 & 4.2 & 4.4 \\
\hline Groundnut meal & 10 & 10 & 10 \\
\hline Soybean meal & 5 & 5 & 5 \\
\hline Fishmeal & 10 & 10 & 10 \\
\hline Fish oil & 2.5 & 2.5 & 2.5 \\
\hline Oyster shell & 0.6 & 0.6 & 0.6 \\
\hline Dicalcium phosphate & 0.2 & 0.2 & 0.2 \\
\hline Vitamin-minerals premix* & 0.4 & 0.2 & - \\
\hline Lysine & 0.2 & 0.2 & 0.2 \\
\hline Methionine & 0.1 & 0.1 & 0.1 \\
\hline Total & 100 & 100 & 100 \\
\hline Calculated nutrients & & & \\
\hline ME (kcal/kg) & 3191.36 & 3195.99 & 3200.62 \\
\hline CP (\%) & 19.96 & 19.99 & 20.02 \\
\hline Energy protein ratio & 159.86 & 159.88 & 159.91 \\
\hline
\end{tabular}

*Broiler premix supplied/kg: Vitamin A- 5,000,000 IU; Vitamin D3- 600,000 IU; Vitamin E- 2,000 mg,; Vitamin K3- 2,000 mg; Vitamin B1- 2,000 mg; Vitamin B2- 2,000 mg; Vitamin B6- 2,000 mg; Vitamin B12- $5 \mathrm{mg}$; Vitamin C- 1,000 mg; Calcium pantothenate- 5,000 mg; Nicotinamide- 15,000 mg; Maganese sulfate- 40,000 mg; Zinc sulfate- 40,000 mg; Iron sulfate- 20,000 mg; Copper sulfate- 3,000 mg; Cobalt sulfate- $100 \mathrm{mg}$; Potassium Iodide- $100 \mathrm{mg}$; Folic acid- $100 \mathrm{mg}$; Methionine- 10,000 mg; Lysine- 10,000 $\mathrm{mg}$

Table 2- Proximate composition of fresh water spinach (Ipomoea aquatica)

\begin{tabular}{|l|l|l|}
\hline Water spinach & Fresh basis & DM basis \\
\hline Moisture \% & 92.5 & 7.5 \\
\hline Crude protein \% & 2.1 & 28 \\
\hline Vitamin A & $869 \mathrm{RE} / 100 \mathrm{~g}$ or 2899 IU/100g or & - \\
& $1.58 \mathrm{mg} / 100 \mathrm{~g}$ as Retinyl palmitate & \\
\hline
\end{tabular}

Table 3- The cost differences among dietary treatments by using premix

\begin{tabular}{|c|c|c|c|c|c|c|}
\hline \multirow{2}{*}{$\begin{array}{l}\text { Premix } \\
\text { (kyats/kg) }\end{array}$} & \multirow{2}{*}{$\begin{array}{l}\text { Age } \\
\text { (Day) }\end{array}$} & \multicolumn{2}{|c|}{$\begin{array}{c}\text { Treatment } 1 \\
\text { (40 birds) }\end{array}$} & \multicolumn{2}{|c|}{$\begin{array}{c}\text { Treatment } 2 \\
\text { (40 birds) }\end{array}$} & \multirow{2}{*}{$\begin{array}{l}\text { Total cost } \\
\text { (T1 and } \mathrm{T} 2 \text { ) }\end{array}$} \\
\hline & & $\begin{array}{l}\text { Premix } \\
\text { usage }(g)\end{array}$ & Cost (kyats) & $\begin{array}{l}\text { Premix } \\
\text { usage }(\mathrm{g})\end{array}$ & Cost (kyats) & \\
\hline 11000 & $22-28$ & 121.6 & 1337.6 & 60.8 & 668.8 & 2006.4 \\
\hline 11000 & $29-35$ & 164 & 1804 & 82 & 902 & 2706 \\
\hline 11000 & $36-42$ & 212.8 & 2340.8 & 106.4 & 1170.4 & 3511.2 \\
\hline 11000 & $43-49$ & 247.2 & 2719.2 & 123.6 & 1359.6 & 4078.8 \\
\hline \multicolumn{2}{|c|}{ Total } & 745.6 & 8201.6 & 372.8 & 4100.8 & 12302.4 \\
\hline
\end{tabular}

Table 4- The cost differences among dietary treatments by using water spinach (WS)

\begin{tabular}{|c|c|c|c|c|c|c|}
\hline \multirow{2}{*}{$\begin{array}{l}\text { WS (kyats/ viss } \\
1632.93 \mathrm{~g}\end{array}$} & \multirow[b]{2}{*}{ Age (Day) } & \multicolumn{2}{|c|}{ Treatment 2 (40 birds) } & \multicolumn{2}{|c|}{ Treatment 3 (40 birds) } & \multirow{2}{*}{$\begin{array}{l}\text { Total cost } \\
\text { (T2 and T3) }\end{array}$} \\
\hline & & $\begin{array}{l}\text { WS usage } \\
(\mathrm{g})\end{array}$ & $\begin{array}{l}\text { Cost } \\
\text { (kyats) }\end{array}$ & WS usage $(\mathrm{g})$ & Cost (kyats) & \\
\hline 100 & $22-28$ & 7824.6 & 479.18 & 15649.2 & 958.35 & 1437.53 \\
\hline 100 & $29-35$ & 10819.2 & 662.56 & 21638.4 & 1325.13 & 1987.69 \\
\hline 100 & $36-42$ & 13524 & 828.20 & 27048 & 1656.41 & 2484.61 \\
\hline 100 & $43-49$ & 16422 & 1005.68 & 32844 & 2011.35 & 3017.03 \\
\hline \multicolumn{2}{|c|}{ Total } & 48589.8 & 2975.62 & 97179.6 & 5951.24 & 8926.86 \\
\hline
\end{tabular}

weights were selected. The birds were placed in individual cages and fed with their specific experimental diet. Feed intake was recorded for each bird every day, and the faeces were collected on a plastic sheet. The split feathers of the bird, dropped feed particles, and other foreign materials were removed carefully from 
the collected faeces. Total faeces were collected on three consecutive days and sun dried. After completion of the trial, faecal samples of each bird were placed in the oven for drying and the dried samples were ground for determination of DM and CP.

\section{Chemical and Statistical analyses}

The determination of nutrient compositions of water spinach, feed ingredients and faeces samples was carried out according to AOAC (2005) at the Department of Agriculture Research, Yezin, Nay Pyi Taw, and the Veterinary Assay Laboratory, Livestock Breeding and Veterinary Department, Insein Township, Yangon. The data were subjected to ANOVA using general linear model (GLM) procedure of SAS ${ }^{\circledR}$ (SAS® Institute, 2002) as a RCBD experiment.

\section{Results}

\section{Chemical composition of water spinach}

The proximate composition of the vitamin A, moisture, DM and CP in fresh water spinach showed in Table 2.

\section{Growth performance}

Cumulative feed consumption, final body weight, cumulative weight gain and cumulative feed conversion ratio (FCR) of broilers are shown in Table 5. There were no significant $(\mathrm{P}>0.05)$ differences among the dietary treatments on the cumulative feed consumption, final body weight, cumulative weight gain and cumulative FCR of broilers even though water spinach was offered as fresh material to broiler chickens, no left-overs were found.

Digestibility of nutrients

Digestibility of DM and CP of experimental diets is shown in Table 6. The digestibility of DM among dietary treatments did not differ significantly $(\mathrm{P}>0.05)$ from one another. The digestibility of $\mathrm{CP}$ for broilers was also not significantly $(\mathrm{P}>0.05)$ different among dietary treatments.

Table 5- Cumulative feed intake, final body weight, cumulative weight gain and cumulative feed conversion ratio (FCR) of broilers (On days 22-49)

\begin{tabular}{|l|l|l|l|l|}
\hline \multirow{2}{*}{ Performance } & \multicolumn{3}{|c|}{ Treatments (Mean+SEM) } & \multicolumn{1}{l|}{$\begin{array}{l}\text { Significant } \\
\text { level }\end{array}$} \\
\cline { 2 - 5 } & \multicolumn{1}{|c|}{ Diet 1 } & \multicolumn{1}{|c|}{ Diet 2 } & \multicolumn{1}{c|}{ Diet 3 } & NS \\
\hline Cumulative feed intake & $3727.5 \pm 59.88$ & $3863.4 \pm 97.59$ & $3928.4 \pm 62.95$ & NS \\
\hline Final body weight & $2433.9 \pm 71.53$ & $2471.0 \pm 75.65$ & $2468.3 \pm 26.43$ & NS \\
\hline Cumulative weight gain & $1846.3 \pm 58.01$ & $1870.8 \pm 75.77$ & $1875.6 \pm 24.90$ & NS \\
\hline Cumulative FCR & $2.0 \pm 0.04$ & $2.1 \pm 0.04$ & $2.1 \pm 0.02$ & \\
\hline
\end{tabular}

The means within the same row are not significantly different at ( $\mathrm{P}>0.05)$ (ANOVA).

NS = Not significant, SEM $=$ Standard error of mean, Diet $1=$ basal diet containing $0.4 \%$ vitamin-mineral premix (control), Diet 2 = basal diet containing $0.2 \%$ vitamin-mineral premix $+34.5 \mathrm{~g}$ fresh water spinach (Ipomoea aquatica), Diet $3=$ basal diet without vitamin-mineral premix $+69 \mathrm{~g}$ fresh water spinach

Table 6- Digestibility of dry matter and crude protein of experimental diets

\begin{tabular}{|c|c|c|c|c|}
\hline \multirow{3}{*}{$\begin{array}{l}\text { Digestibility } \\
\text { (\% of DM basis) }\end{array}$} & \multicolumn{3}{|c|}{$\begin{array}{l}\text { Digestibility of DM and CP of experimental diets } \\
(\text { (Mean } \pm \text { SEM })\end{array}$} & \multirow{3}{*}{$\begin{array}{c}\text { Significant } \\
\text { level }\end{array}$} \\
\hline & \multicolumn{3}{|c|}{ Treatments } & \\
\hline & Diet 1 & Diet 2 & Diet 3 & \\
\hline Dry matter & $69.3 \pm 1.67$ & $67.1 \pm 1.99$ & $68.3 \pm 1.21$ & NS \\
\hline Crude protein & $73.7 \pm 1.51$ & $72.1 \pm 1.78$ & $72.7 \pm 2.16$ & NS \\
\hline
\end{tabular}

The means within the same row are not significantly different at $(\mathrm{P}>0.05)$ (ANOVA).

NS = Not significant, SEM $=$ Standard error of mean, Diet $1=$ basal diet containing $0.4 \%$ vitamin-mineral premix (control), Diet 2 = basal diet containing $0.2 \%$ vitamin-mineral premix $+34.5 \mathrm{~g}$ fresh water spinach (Ipomoea aquatica), Diet $3=$ basal diet without vitamin-mineral premix $+69 \mathrm{~g}$ fresh water spinach 


\section{Discussion}

\section{Chemical composition of water spinach}

Water spinach used in this experiment had vitamin A content of only $1.58 \mathrm{mg} / 100 \mathrm{~g}$ and it was lower than that of $2.9 \mathrm{mg} / 100 \mathrm{~g}$ in an earlier study carried out by Kejanny (2014). The difference might be due to the differences in storage and rate of maturity of vegetables, and also different assay method used for vitamin determination. Ismail et al. (2013) reported that vitamin contents of fruits and vegetables can vary with small variations worldwide because of environmental factors on soil, air and water.

Water spinach possessed $92.5 \%$ moisture and 7.5\% DM in this study. This was similar to other reports that the average moisture and DM contents were $92.98 \%$ and $7.02 \%$ of water spinach leaves and stems in Vietnam (Nguyen Thi Thuy and Ogle, 2005), and $92.66 \%$ and $7.34 \%$ of water spinach leaves in Cambodia (Pok Samkol, 2005). However, the DM content was lower than in other studies; $12.9 \%$ (Phimmmasan et al., 2004); $10.8 \%$ (Dong et al., 2006); $11.4 \%$ (Saroeun, 2010); 13.4 (Ahemen et al., 2015); and $13.7 \%$ (Phongphanith et al., 2012) respectively.

Water spinach had $2.1 \% \mathrm{CP}$ on fresh basis in the present study. It was higher than in other studies that reported a CP component of fresh leaves of water spinach of $1.9 \%$ (Pok Samkol, 2009) and $1.7 \%$ (Igwenyi et al., 2011). However, it was lower than that found $(2.7 \%$ CP) in a study carried out by Kejanny (2014). On a DM basis, water spinach had $28 \% \mathrm{CP}$ in this study. This data was in agreement with the $28 \%$ CP in DM found by Men et al. (2000). However, it was higher than the values $(24.6 \%, 24 \%$ and $23.7 \%$ CP in DM) reported by Khamparn and Preston, 2006; Saroeun, 2010; Phongphanith et al., 2012; but lower than the values $(31.9 \%, 35.9 \%$ and $36.3 \%$ CP in DM) reported by Nguyen Thi Thuy and Ogle, 2005; Phimmmasan et al., 2004 and Dong et al., 2006. Gakuya et al., (2014) suggested that the levels of crude protein might be influenced by the stage of leaf harvest and the agro-climatic conditions of the area. Also variations on nutrient composition could be a result of environmental factors such as season, geographical condition, location, stage of maturity and processing methods (Wafer and Tarimbuka, 2016).

\section{Growth performance}

Although it was expected that the supplementation of green feed (water spinach) to basal diets would stimulate the growth performance of broilers, there were no significant $(\mathrm{P}>0.05)$ effects on feed intake, body weight, weight gain and FCR of broilers among dietary treatments.

The results of the present study were in agreement with the findings of Nguyen Thi Thuy and Ogle (2005) who indicated that basal diet supplemented with water spinach to layer chickens had no significant effect on feed intake, weight gain and FCR when compared with the control diet. Unigwe et al., (2016) also reported that broiler chickens fed diets containing different levels $(0 \%, 5 \%, 10 \%$ and $15 \%)$ of sweet potato (Ipomoea batatas) leaf meal showed no significant effect on average body weight gain, feed intake, FCR and protein efficiency ratio. The result from this study was also in agreement with the observation by Paguia et al. (2014) who established that using different amounts of Moringa oleifera leaf meal (0\%, 0.2 $\%, 0.3 \%, 0.4 \%, 0.5 \%$ ) in broiler and layer ration, did not significantly influence the broiler' feed intake, weight gain, final body weight and FCR, and also had non-significant effects on feed consumption, FCR and egg production in layer chickens. It seemed that the incorporation levels of leaf meals did not affect the palatability of the diets (Odulate et al., 2014). Nguyen Thi Thuy and Ogle (2005) also suggested that the lack of effect of the green feeds on growth rate, feed conversion and meat quality was probably due to the fact that the basal diet was already well balanced in major nutrients.

The present results contrasted with some of the following observations which reported the use of various kinds of green feed in poultry production. Onyimonyi and Onu Ernest (2009) reported that finisher broilers receiving pawpaw leaf meal $(0.5 \%, 1.5 \%$ and $2 \%)$ showed significantly effects on daily and average weight gain, final body weight and FCR compared with the control. Similar findings were reported by Offor and Wariboko (2013) who found that birds fed diets supplemented with leguminous plants (Centrosema pubescenes) had higher average weight gain than the control group. It could be due to the fact that fresh leaves are succulent and stimulate appetite in birds which invariably increase consumption of feed (Oluyemi and Roberts, 1988). Angas et al. (2018) also agreed that diet containing 1\% Heracleum persicum and $1 \%$ Echinacea angustifolia medical plants improved the average weight gain and FCR of quail. It may be due to some effective substances in these plants can have stimulating effects on increasing the secretions of digestive latexes, which may leads to better digestion, absorption and metabolism of nutrients. Then, effective growth performance might also be as a result of the vitamins, minerals and trace food nutrients derived from the consumed leaves (Offor and Wariboko, 2013).

Several findings were inconsistent regarding the supplementation effect of plant extracts and/ or leaf meals in broiler diets. Some suggested that it had positive effects on chick performance while others found reduced feed intake, body weight gain and FCR (Lee et al., 2003; Cross et al., 2007). Ekenyem and Madubuike (2006) reported that a low level (5\%) of Ipomoea asariforia leaf meal had no significant effect on broiler' feed intake, weight gain and final body weight compared with control diet but high levels (10\% and $15 \%$ ) showed significant reduction in growth performance. Similar observation by Tagoe et al. (2014) 
who reported that broiler offered Alternanthera sessilis leaf meal supplement at $0.5 \%$ level of inclusion compared favourably with the control, while high levels $(0.75 \%, 1 \%$ and $1.25 \%)$ supplementation had negative effect on growth performance. The lower growth response was probably caused by reduced palatability of the diet which causes reduction in feed intake (Odulate et al., 2014). Ghazalah and Ali (2008) who suggested that the decrease in growth as dietary leaf meal increased could be caused by the high crude fibre content in particular cellulose from the cell walls of leaf meal, which may impede the utilization of nutrients by chicks. Unigwe et al., (2016) also reported that this could be due to higher antinutrients in high levels leaf meal supplemented diet than those in low levels supplementation. However, the very low levels of water spinach substitution in this study are comparable to the results of other studies when offering such low levels of leaf meals.

The present study was performed to replace (part of) vitamin-mineral premix by using fresh water spinach. The inclusion level of water spinach by DM basis was not very high (diet $2=2.6 \%$ and $\operatorname{diet} 3=5.2$ $\%$ ), thus, it could not significantly effect on feed intake, body weight gain, final body weight and FCR. Possibly in the future, there might be a good prospect of making wider use of water spinach (Ipomoea aquatica) in broiler ration.

\section{Digestibility trial}

In this study, the digestibility of feed DM and feed CP did not differ significantly $(\mathrm{P}>0.05)$ among dietary treatments. The results of the present study contrasted with some of the observations in different kinds of green feed supplementation in chickens. Gakuya et al. (2014) who observed that supplementation of Moringa oleifera leaf meal $(7.5 \%, 15 \%$ and $30 \%)$ in broiler chicken feed reduced digestibility of DM and CP when compared to control. Similar results with broilers are reported by Iheukwumere et al. (2008), where the utilisation values of DM and CP were lower in 10 and $15 \%$ cassava leaf meal than its control. Furthermore, Ige et al. (2006) reported that layer chicken fed on different levels (5\%,10\% and $15 \%)$ of gliricidia leaf meal to basal diet reduced digestibility of DM and CP compared with control. Abou-Elezz et al. (2012) also stated that feeding hens at 0, 5, 10 and 15\% Leucaena leucocephala and Moringa oleifera leaf meals separately, the digestibility coefficients revealed a linear reduction in DM and CP by increase of leaf meals supplementation. Poor nutrient utilisation observed could be in general due to the increased fibre content of the diets with higher green leaf meal levels, also attributed to the low capacity of the chicken digestive system in utilising the high fibrous feeds. Nyman et al. (1990) also reported that the low digestibility of $\mathrm{CP}$ observed in high fibre is attributed to the indigestible cell wall which reduces the digestion and absorption of protein overall. Otherwise, the present results are in accordance with the finding of the Nkukwana et al. (2014) who reported that supplementing Moringa oleifera leaf meal to broiler chickens at 5,15 and $25 \mathrm{~g}$ per $\mathrm{kg}$ of feed and had no significant effect on utilisation values of DM and CP. It might be due to the digestibility was not affected as the inclusion levels of leaf meal was too low.

\section{Conclusions}

According to the present findings, there were no significant effects on growth performances and nutrients digestibility among dietary treatments. There were no adverse effects on growth performance and nutrients digestibility of broiler chickens fed diet supplemented with water spinach. Therefore, it can be concluded that the cheaper and easily available water spinach can replace the costly vitamin-mineral premix used in the formulation of broiler's diet. Continuous studies are needed on good prospect of making wider use of water spinach regards with their optimal inclusion levels in diets of broiler chickens generally to further reduce cost and improve growth performance.

\section{Conflict of interest}

All authors have approved the submission of this manuscript and do declare that there is no conflict of interest. The manuscript has not been published previously and is not under consideration for publication elsewhere.

\section{References}

1) Abou-Elezz FMK, Sarmiento-Franco L, Santos-Ricalde R, Solorio-Sanchez F, 2012. Apparent digestibility of Rhode Island Red Hen's diets containing Leucaena leucocephala and Moringa loeifera leaf meals. Tropical and Subtropical Agroecosystems 15: 199-206.

2) Ahemen T, Abu AH, Anongu TT, 2015. The effect of feeding varying levels of water spinach (Ipomoea aquatica) leaf meal on reproductive tract morphometry, haematology and serum biochemical parameters of female rabbits. Middle-East Journal of Scientific Research 23: 2792-2796.

3) Angas MR, Tabrizi HM, Pourelmi M, Abdollahi M, 2018. Effect of the Heracleum persicum and Echinacea angustifolia levels on performance in of male Japanese quail. Journal of Livestock Science 9: 96-100. 
4) AOAC, 2005. Official Methods of Analysis. Association of Official Analytical Chemists. $18^{\text {th }}$ Edition. Washington DC.

5) Cross DE, McDevitt RM, Hillman K, Acamovic T, 2007. The effect of herbs and their associated essential oils on performance, dietary digestibility and gut micro-flora in chickens from 7 to 28 days of age. British Poultry Science 48: 496-506.

6) Dong, NTK, Thu NV, Ogle B, Preston TR, 2006. Effect of supplementation level of water spinach (Ipomoea aquatica) leaves in diets based on para grass (Brachiaria mutica) on intake, nutrient utilization, growth rate and economic returns of crossbred rabbits in the Mekong Delta of Vietnam. MSc Thesis, Swedish University of Agricultural Sciences, Uppsala.

7) Ekenyem, BU, Madubuike F, 2006. An assessment of Ipomoea asarifolia leaf meal as feed ingredient in broiler chick production. Pakistan Journal Nutrition 5: 46-50.

8) Gakuya DW, Mbugya PN, Kavoi B, Kiama SG, 2014. Effect of supplementation of Moringa oleifera leaf meal in broiler chicken feed. International Journal of Poultry Science 13: 208-213.

9) Ghazalah AA, Ali AM, 2008. Rosemary leaves as a dietary supplement for growth in broiler chickens. International Journal of Poultry Science 7: 234-239.

10) Ige AO, Odunsi AA, Akinlade JA, Ojedapo LO, Ameen SA, Aderinola OA, Rafiu TA, 2006. Gliricidia leaf meal in layer's diet: Effect on performance, nutrient digestibility and economy of production. Journal of Animal and Veterinary Advances 5: 483-486.

11) Igwenyi IO, Offor CE, Ajah DA, Nwankwo OC, Ukaomah JI, Aja PM, 2011. Chemical compositions of Ipomoea aquatica (green Kangkong). International Journal of Pharm and Bio Sciences 4: 594-598.

12) Iheukwumere FC, Ndubuisi EC, Mazi EA, Onyekwere MU, 2008. Performance nutrient utilization and organ characteristics of broilers fed cassava leaf meal (Manihot esculenta Crantz). Pakistan Journal of Nutrition 13: 13-16.

13) Ismail F, Farah NT, Memon AN, 2013. Determination of water soluble vitamin in fruits and vegetables marked in Sindh Pakistan. Pakistan Journal of Nutrition 12: 197-199.

14) Kejanny, 2014. Kangkong (or water spinach) uses, nutrition facts and health benefits. Accessed 20 October 2014. https://hubpages.com/ food/Kangkong-or-Water-Spinach-Uses-Nutritional-Factsand-Health-Benefits.

15) Khamparn P and Preston TR (2006). Effect of supplement of fresh water spinach (Ipomoea aquatica) on feed intake and digestibility in goats fed a basal diet of cassava foliage. Livestock Research for Rural Development 3: 1-7.

16) Lee KW, Everts H, Kappert HJ, Yeom KH, Beynen AC, 2003. Dietary carvacrol lowers body weight gain but improves feed conversion in female broiler chickens. Journal of Applied Poultry Research 12: 394-399.

17) Men LT, Ogle B, Son VV, 2000. Evaluation of water spinach as a protein source for Baxuyen and Large White sows. MSc Thesis, Cantho University, Vietnam.

18) Naren Toung, Ogle RB, Preston TR, 1994. Optimum protein supply and level of inclusion of water spinach (Ipomoea aquatica) in sugar cane juice based diets for growing ducks. MSc Thesis, Swedish University of Agricultural Science, Uppsala.

19) Nguyen Thi Thuy, Ogle B, 2005. The effect of supplementing different green feeds (water spinach, sweet potato leaves and duckweed) to broken rice based diets on performance, meat and egg yolk colour of Luong Phuong chickens. Workshop-seminar "Making better use of local feed resources", MEKARN-CTU, Cantho, May 23-25.

20) Nkukwana TT, Muchenje V, Pieterse E, Masika PJ, Mabusela TP, Hoffman LC, Dzama K, 2014. Effect of Moringa oleifera leaf meal on growth performance, apparent digestibility, digestive organ size and carcass yield in broiler chickens. Livestock Science 161: 139-146.

21) NRC, 1994. Nutrient Requirements of Poultry. National Research Council (NRC), National Academy Press. ${ }^{\text {th }}$ Edition. Washington DC.

22) Nyman M, Schweizer TF, Tyren S, Reimann S, Asp NG, 1990. Fermentation of vegetable fiber in the intestinal tract of rats and effects on fecal bulking and bile acid excretion. Journal of Nutrition 120: $459-466$.

23) Odulate DO, Idowu AA, Fabusoro AA, Odebiyi CO, 2014. Growth performance of juvenile Clarias gariepinus fed Ipomoea aquatica based diets. Journal of Fisheries and Aquatic Science 9: 468-472.

24) Offor US, Wariboko ON, 2013. Effects of leguminous plants (Centrosema pubescens) as feed additive for growth stimulation on broilers. World Journal of Agricultural Sciences 1: 299-302.

25) Oluyemi JA, Roberts FA, 1988. Poultry Production in the Warm Climates. Low Cost, edited by Macmillan, 133-139. London.

26) Onyimonyi AE, Onu Ernest 2009. An assessment of paw-paw leaf meal as protein ingredient for finishing broiler. International Journal of Poultry Science 10: 995-998. 
27) Oomen HC, Grubben A, 1978. Tropical leaf vegetables in human nutrition. Journal of Agriculture 20: 69-75.

28) Paguia HM, Paguia RQ, Balba C, Flores RC, 2014. Utilization and evaluation of Moringa oleifera leaf as poultry feeds. APCBEE Procedia 8: 343-347.

29) Phimmmasan H, Kongvongxay S, Chhay Ty, Preston TR, 2004. Water spinach (Ipomoea aquatica) and Stylo 184 (Stylosanthes guianesis CIAT 184) as basal diets for growing rabbits. Livestock Research for Rural Development 16: 5.

30) Phongphanith S, Vilaysack V, Inthapanya S, Preston TR, 2012. Effect on growth performance of ducks of supplementing a basal diet of rice bran with water spinach, duckweed or ensiled taro leaves. MSc Thesis, Souphanouvong University, Lao.

31) Pok Samkol, 2005. Water spinach (Ipomoea aquatica) as a feed resource for growing rabbits. MSc Thesis, Swedish University of Agricultural Science, Uppsala.

32) Pok Samkol, 2009. Water spinach (Ipomoea aquatica) as a feed resource for growing rabbits. Revista Computadorizada de Producción Porcina 16: 91-99.

33) Prasad NK, Shivamurthy GR, Aradhya SM, 2008. Ipomoea aquatica, An underutilized green leafy vegetable. International Journal of Botany 4: 123-129.

34) Saroeun K, 2010. Feed selection and growth performance of local chickens offered different carbohydrate sources in fresh and dried form supplemented with protein rich forages. MVSc Thesis, Swedish University of Agricultural Science, Uppsala.

35) $\mathrm{SAS}^{\circledR}$ Institiute, 2002. SSAT/ STAT User's Guide Release Version 6.03 Edition. SAS ${ }^{\circledR}$ institute Inc, Cary, NC.

36) Tagoe NAA, Atuahene CC, Adjei MB, 2014. Response of broiler chickens to dietary inclusion of Alternanthera sessilis leaf meal (ASLM). Journal of Animal Science Advances 4: 648-657.

37) Teguia A, Beynen AC, 2005. Alternative feedstuffs for broilers in Cameroon. Livestock Research for Rural Development 17: 3.

38) Unigwe CR, Ononogbu CE, Adejuyigbe AD, Abonyi FO, 2016. Growth performance and haematology of broiler chickens fed diets with graded sweet potato (Ipomoea batatas) leaf meals. World Scientific News 56: 45-55.

39) Wafer RJ, Tarimbuka LT, 2016. Effects of substitute groundnut cake with water spinach (Ipomoea aquatica) leaf meal on performance, carcass yield and blood profile of weaner rabbit. FUW Trends in Science and Technology Journal 1: 238-242. 